\title{
Influence of Nutrient on Growth of Some Freshwater Algae of Vena River in Hinganghat Area of Dist. Wardha
}

\author{
B. M. Rajurkar' ${ }^{1}$ L. P. Dalal ${ }^{2}$ \\ ${ }^{1}$ Assistant Professor, Department of Botany, R. S. Bidkar College, Hinganghat, Dist. Wardha, India \\ ${ }^{2}$ Associate Professor, Department of Botany, J. B. College of Science, Wardha (M.S.), India
}

\begin{abstract}
The present study reports on influence of nutrient on growth of freshwater algal taxa of Vena River in Hinganghat area of Wardha District. The algal taxa like Oscillatoria, Chloroccocum, Selenastrum and Coelastrum were studied and reported influence of Carbon, Nitrogen, Phosphorous, Magnesium, Potassium, Chloride and Iron from June 2011 to May 2013.
\end{abstract}

Keywords: Algae; Aquatic ecosystem; Eutrophication; Vena river

\section{Introduction}

The present research enables to know the influence of nutrient on growth of freshwater algal taxa of Vena river in Hinganghat area of Wardha District, which is a part of Vidarbha, Maharashtra state. The study was made over a period of two years of intensive study i.e. June 2011 to May 2013. It has been investigated by Marathe, (1969) and Jawale and Chaudhari, (2010) that algae occurs in sufficient quantities to render its commercial applications.

Hinganghat is one of the tehsils of Wardha District situated in $20^{\circ} 18^{\prime}$ to $20^{\circ} 49^{\prime} \mathrm{N}$ and $78^{0} 32^{\prime}$ to $79^{\circ} 14^{\prime}$ E latitude. The town is located on the bank of river Vena, a tributary of the Wardha river which joins the big river Pranhita ahead at a distant place, which ultimately merges into the Godavari river later. In British India, Hinganghat was the centre of India, but after the partition of Hindusthan into India, and Pakistan, Nagpur is considered as the center (heart place) of India. At Vena river pump house, there is a historical old stone, on which it is mentioned that Hinganghat is the centre of India. Major portion of the total annual rainfall is received from the months of June to September of every year. The average rainfall of Hinganghat Tahsil is $1071.70 \mathrm{~mm}$, and has a dry tropical weather climate. The climate is hot, and dry. Max temp. in ${ }^{0} \mathrm{C}$ is noted as $47.9{ }^{0} \mathrm{C}$ and Min. temp. in ${ }^{0} \mathrm{C}$ is noted as $10.2{ }^{0} \mathrm{C}$. The seasons of a year are divided according climates into three namely cold, hot and monsoon. The land scape of the city with fast running streams faces towards the south. Vena River borders the north, west, and south sides of the city. The city is rich in fauna, and flora and water sources. In Hinganghat area, Vena river is a fresh water body, and is one of the prominent rivers of Vidarbha, Maharashtra. It is Perennial River of this area. It is supposed to be the life line of the Wardha district, but due to expanding needs of growing population, it is facing many adversities or changes. The river Vena has received little attention from botanists, ecologists and specially phycologist as such and moreover, the scientific approach has not been holistic. The study of influence of nutrient on growth of freshwater algal taxa of this river is of great importance, and should be known to the peoples, and may be the heritage of future generation.

\section{Materials and Methods}

Vena River is one of the major water bodies of Hinganghat region in Wardha District, Vidarbha. Stations SW1 (Underbridge), SW2 (Kawalghat), SW3 (Smashanbhoomi), and SW4 (Shahalangadi) were selected near Hinganghat area. Water samples were collected from June 2011 to May 2013. These samples were analysed for determining the algal taxa. The macroscopic algae were manually picked with forceps and microscopic algae with the help of a planktonic net (pore size less than $40 \mu \mathrm{m}$ ). The samples were immediately brought to the laboratory for the taxonomical documentation of algal taxa and preserved in $4 \%$ formalin for reference purpose. Preserved samples were studied after the proper settlement of the algal debris. The samples were examined under binocular microscope with attached MIPS for the identification of algal groups and photographs were taken. Algal identification was carried out with the help of available taxonomic literature.

\section{Observations}

Influence of Carbon (mg/l) on algal growth

\begin{tabular}{|c|c|c|c|c|}
\hline $\begin{array}{c}\text { Concentration } \\
\text { in } \mathrm{mg} / \mathrm{l}\end{array}$ & Oscillatoria & Chloroccocum & Selenastrum & Coelastrum \\
\hline 1 & 27 & 1.303 & 1.21 & 1.248 \\
\hline 2 & 29 & 1.323 & 1.22 & 1.289 \\
\hline 2.266 & 28 & 1.374 & 1.298 & 1.263 \\
\hline 4 & 26 & 1.31 & 1.021 & 1.107 \\
\hline 8 & 27 & 1.108 & 1.2 & 1.028 \\
\hline 12 & 22 & 1.028 & 0.932 & 0.942 \\
\hline 16 & 21 & 1.026 & 0.913 & 0.931 \\
\hline
\end{tabular}




\section{International Journal of Science and Research (IJSR) ISSN (Online): 2319-7064}

Index Copernicus Value (2013): 6.14 | Impact Factor (2015): 6.391

Influence of Nitrogen (mg/l) on algal growth.

\begin{tabular}{|c|c|c|c|c|}
\hline $\begin{array}{c}\text { Concentration } \\
\text { in mg/l }\end{array}$ & Oscillatoria & Chloroccocum & Selenastrum & Coelastrum \\
\hline 200 & 25 & 1.592 & 1.501 & 1.682 \\
\hline 242 & 22 & 1.602 & 1.5 & 1.598 \\
\hline 250 & 25 & 1.604 & 1.522 & 1.684 \\
\hline 300 & 28 & 1.611 & 1.599 & 1.701 \\
\hline 350 & 22 & 1.503 & 1.41 & 1.68 \\
\hline 400 & 19 & 1.59 & 1.51 & 1.675 \\
\hline 450 & 20 & 1.541 & 1.44 & 1.638 \\
\hline
\end{tabular}

Influence of Phosphorous (mg/l) on algal growth. Concentration Oscillatoria Chloroccocum Selenastrum |Coelastrum

\begin{tabular}{|c|c|c|c|c|} 
in $\mathrm{mg} / \mathrm{l}$ & & & & \\
\hline 4 & 21 & 1.246 & 1.181 & 1.271 \\
\hline 7.1 & 18 & 1.405 & 1.39 & 1.423 \\
\hline 8 & 17 & 1.33 & 1.278 & 1.383 \\
\hline 16 & 15 & 1.421 & 1.372 & 1.489 \\
\hline 32 & 14 & 1.278 & 1.2 & 1.421 \\
\hline 64 & 12 & 1.227 & 1.157 & 1.253 \\
\hline 128 & 10 & 1.69 & 1.068 & 1.198 \\
\hline
\end{tabular}

Influence of Magnessium (mg/l) on algal growth.

\begin{tabular}{|c|c|c|c|c|}
\hline $\begin{array}{c}\text { Concentration } \\
\text { in } \mathrm{mg} / \mathrm{l}\end{array}$ & Oscillatoria & Chloroccocum & Selenastrum & Coelastrum \\
\hline 4 & 23 & 1.482 & 1.435 & 1.512 \\
\hline 7.3 & 26 & 1.605 & 1.525 & 1.64 \\
\hline 8 & 29 & 1.55 & 1.509 & 1.586 \\
\hline 16 & 25 & 1.588 & 1.579 & 1.721 \\
\hline 32 & 23 & 1.703 & 1.528 & 1.623 \\
\hline 64 & 21 & 1.698 & 1.528 & 1.737 \\
\hline 128 & 18 & 1.233 & 1.539 & 1.5 \\
\hline
\end{tabular}

Influence of Potassium (mg/l) on algal growth.

\begin{tabular}{|c|c|c|c|c|}
\hline $\begin{array}{c}\text { Concentration } \\
\text { in } \mathrm{mg} / \mathrm{l}\end{array}$ & Oscillatoria & Chloroccocum & $\begin{array}{c}\text { Selenastr } \\
\text { um }\end{array}$ & Coelastrum \\
\hline 4 & 29 & 1.307 & 1.279 & 1.34 \\
\hline 8 & 17 & 1.405 & 1.38 & 1.423 \\
\hline 16 & 21 & 0.99 & 1.374 & 1.427 \\
\hline 17.95 & 23 & 1.39 & 1.369 & 1.421 \\
\hline 32 & 14 & 1.426 & 1.401 & 1.42 \\
\hline 64 & 13 & 1.41 & 1.393 & 1.441 \\
\hline 128 & 9 & 1.4 & 1.373 & 1.425 \\
\hline
\end{tabular}

Influence of Chloride (mg/l) on algal growth.

\begin{tabular}{|c|c|c|c|c|}
\hline $\begin{array}{c}\text { Concentration } \\
\text { in } \mathrm{mg} / \mathrm{l}\end{array}$ & Oscillatoria & Chloroccocum & Selenastrum & Coelastrum \\
\hline 4 & 23 & 1.397 & 1.309 & 1.482 \\
\hline 8 & 24 & 1.425 & 1.345 & 1.537 \\
\hline 16 & 28 & 1.432 & 1.343 & 1.535 \\
\hline 23.99 & 24 & 1.403 & 1.318 & 1.492 \\
\hline 32 & 23 & 1.438 & 1.35 & 1.551 \\
\hline 64 & 21 & 1.41 & 1.325 & 1.506 \\
\hline 128 & 18 & 1.341 & 1.253 & 1.44 \\
\hline
\end{tabular}

Influence of Iron (mg/l) on algal growth.

\begin{tabular}{|c|c|c|c|c|}
\hline $\begin{array}{c}\text { Concentration } \\
\text { in } \mathrm{mg} / \mathrm{l}\end{array}$ & Oscillatoria & Chloroccocum & Selenastrum & Coelastrum \\
\hline 0.2 & 24 & 1.72 & 1.58 & 1.75 \\
\hline 1.20 & 28 & 1.737 & 1.598 & 1.805 \\
\hline 2 & 22 & 1.7 & 1.591 & 1.8 \\
\hline 4 & 21 & 1.32 & 1.231 & 1.421 \\
\hline 8 & 18 & 1.29 & 1.582 & 1.41 \\
\hline 16 & 16 & 1.24 & 1.18 & 1.441 \\
\hline
\end{tabular}

\section{Result}

In this investigation the maximum growth of Chloroccocum humicalum and Selenastrum westii was recorded as same in concentration of carbonate which is one of the components of basal medium. The maximum growth of Chloroccocum humicalum and Oscillatoria amphibia was observed at 300 $\mathrm{mg} / \mathrm{l}$ of nitrogen.

In present investigation it is found that the magnesium requirement of Chlorococcum humicolum is $32.00 \mathrm{mg} / \mathrm{l}$, Oscillatoria amphibia $8 \mathrm{mg} / \mathrm{l}$, Selastrum sps $16 \mathrm{mg} / \mathrm{l}$ and Coelastrum sphaericum $64 \mathrm{mg} / \mathrm{l}$. Many workers reported maximum growth of algae at various levels. The tolerance of Chlorella vulgaris is high in high concentration of $\mathrm{Mg}$ salt and it grows considerably over in 0.42 moles $\mathrm{mg} / \mathrm{l}$ as recorded by Trelease and Selsam,(1939).

The results of investigation in accordance with Sharon and Belinger, 1976 who noted optimum uptake occurs at about 8 $\mathrm{mg} / \mathrm{l}$ and lower concentration of $\mathrm{MgSO}_{4}$ inhibit growth of algae.

In the present study maximum growth of Chloroccoum humicolum and Selenastrum westii is found at $32 \mathrm{mg} / \mathrm{l}$ and Oscillatoria amphibia at $4 \mathrm{mg} / \mathrm{l}$ and Coelastrum sphaericum at $64 \mathrm{mg} / \mathrm{l}$. The result is similar to Chlorella vulgaris at 2 $\mathrm{mg} / \mathrm{l}$ of potassium.

In this study, $32 \mathrm{mg} / \mathrm{l}$ chloride is require for maximum growth of Chloroccoum humicolum, Selenastrum westii and Coelastrum sphaericum.

In present investigation $1.20 \mathrm{mg} / \mathrm{l}$ iron which is equal to iron in basal medium is required for Chlorococcum sphaericum. The optimum amount of iron required for growth depends upon species as well as on the composition of media concentration the ideal concentration of $1.8 \times 10^{-7} \mathrm{M}$ to $2.6 \mathrm{x}$ $10^{-8} \mathrm{M}$ was found adequate for the growth of Chlorella (Myers,1944; Hopkins,1930); for the heterotrophic growth of Chlorella pyrenoidosa was found to be $1 \times 10^{-9} \mathrm{M}$ while for autotrophic growth it is $1.8 \times 10^{-5}$ (Esyter, 1962).

\section{Discussion}

The major nutrients for plants are $\mathrm{C}, \mathrm{N}, \mathrm{P}, \mathrm{H}, \mathrm{O}_{2}$ and they form the basis of energy metabolism and synthesis of macronutrients on phytoplankton. Silicon is needed for diatom to build cell walls. Sulphur is essential for protein production by phytoplankton. These elements are required in large amounts and hence they are known as major elements. Minor elements are those required in trace amount that include zinc, iron, manganese, cupper.

In this investigation the relative amounts and concentrations of major nutrients, nitrogen source, micronutrients composition are taken into consideration for maximum growth of algae.

Carbon: Carbon is a constituent of all organic compound protoplasm. It is derived from $\mathrm{CO}_{2}$ carbonates, bicarbonates or organic compounds. The most common method of estimation of carbon absorption in algae is through 


\section{International Journal of Science and Research (IJSR) \\ ISSN (Online): 2319-7064 \\ Index Copernicus Value (2013): 6.14 | Impact Factor (2015): 6.391}

photosynthesis. Infact investigators depicted role of bicarbonate and $\mathrm{CO}_{2}$ for Spirullina, Chlorella, marine diatoms Phaecodyctulum tricoruntum (Richmond et. al, 1982), Dixon and Merrett, (1988); $\mathrm{CO}_{2}$ is only carbon compound which support growth. The amount of $\mathrm{CO}_{2}$ bicarbonate and carbonate ions present in the medium is in equilibrium. Carbon was $2.266 \mathrm{mg} / \mathrm{l}$ in medium. The concentration of carbon selected to find its influence on algal growth in BG11 were 1,2,4,8,12,16 mg/l.

The growth of Chlorococum humicolum and Selenastrum wastii is maximum in $2.26 \mathrm{mg} / \mathrm{l}$ as equal to carbon in basal medium and growth of Oscillotaria amphibian and Coelastrum spharicum is obtained in $2.00 \mathrm{mg} / \mathrm{l}$.

Nitrogen: Nitrogen is one of important constituent of many compounds involved in plant material. It is an essential part of living cells. It becomes limiting factors for growth of algae. The plants are utilized $\mathrm{NO}_{3}, \mathrm{NO}_{2}$ and $\mathrm{NH}_{4}$ as Nitrogen source. In some flagellates especially Euglenoids $\mathrm{NO}_{3}$ and $\mathrm{NO}_{2}$ are not much essential as nitrate. It becomes toxic at higher concentration.

The normal requirement of Nitrogen in cultures of various species of green algae observed by Ketchum and Redfied, (1949), is about $6.5-8.3 \%$ of ash free dry weight. Number of workers reported concentration of Nitrogen required for maximum growth of algae. Rodhe, (1948), Chu, (1942), and Gerloff et al., (1950), reported low concentration of Nitrogen 10.2, $13.6 \mathrm{mg} / \mathrm{l}$ respectively where as Tanda, (1951), Scott, (1944) Mayers and Clark, (1944), Craig et al., (1937), and Geoghegen, (1953), reported higher requirement that is $87,106,350,305 \mathrm{mg} / \mathrm{l}$ of nitrogen respectively.

The growth rate in case of Closterium and Nitzschia are independent of nitrate -Nitrogen concentration between 0.005-0.5 mg/l was reported by Ketchum, 1939.

The influence of $\mathrm{N}$ on algal growth in test experiments, the range of 200-400 mg/l as against normal Nitrogen 247.48 $\mathrm{mg} / \mathrm{l}$ in BG-11 medium. The maximum growth of Chlorococum humicolum, Oscillotaria amphibian, Selenastrum wastii, and Coelastrum spharicum is observed in $300 \mathrm{mg} / \mathrm{l}$ concentration of nitrogen.

Phosphorous: It is important constituents of ATP which plays vital role in energy metabolism of cell. It is involve in metabolism of plants. It is major constituent in algae for normal growth (Myers, 1951; Ketchum, 1954, Krauss, 1958, Provasoli, 1960). The phosphorous requirement for optimum algal growth differs from species to species. Higher concentration of phosphorous inhibit the growth (Chu, 1942) In this investigation phosphorous requirement for Oscillatoria amphibia and selanastrum wastii was $7.1 \mathrm{mg} / \mathrm{l}$ as equal to phosphorous in basal medium and Chloroccoum humicolum and Coelastrum sps is $16 \mathrm{mg} / \mathrm{l}$.

Various researches reported different requirement of phosphorous Rodhe, (1948), Chu, (1942) Gerloff, et al., (1950), recorded low requirement of phosphorous in these media.Tanda, (1951), Scott, (1944) Myers and Clark, (1944), Craig et al., (1993), reported calcium is essential element for all chlorophyll containing plants.
Phosphate range is from $4.00 \mathrm{mg} / \mathrm{l}$ to $128 \mathrm{mg} / \mathrm{l}$. The maximum growth of Oscillatoria amphibia and Selenastrum wastii were observed at $7.1 \mathrm{mg} / \mathrm{l}$ equal to phosphate in basal medium and maximum growth of Chlorococum humicolum and Coelastrum spharicum were observed at the concentration of $16 \mathrm{mg} / \mathrm{l}$.

Magnesium: Magnesium is a component of chloroplast counter ion of ATP important for protein biosynthesis. Magnesium is needed by algae species because nearly all algae have chlorophyll. An adequate concentration of $\mathrm{mg}$ for algae may quite low of Ankistrodesmus sp $0.1 \mathrm{mg} / \mathrm{l}$. The concentration of magnesium was $7.38 \mathrm{mg} / \mathrm{l}$ in basal medium. The elements concentrations taken were 4, 8, 16, 32 and 128 $\mathrm{mg} / \mathrm{l}$. The maximum growth of Oscillatoria amphibian obtained at the concentration of $8.00 \mathrm{mg} / \mathrm{l}$. Maximum growth of Chlorococum humicolum were at $64 \mathrm{mg} / \mathrm{l}$.

Potassium: It is required for all algae under deficient condition. It is major element in algae. The concentration of Potassium was $17.95 \mathrm{mg} / \mathrm{l}$ in basal medium. The elements concentrations taken were 4, 8, 16, 17.95, 32, 64 and 128 $\mathrm{mg} / \mathrm{l}$. The maximum growth of Oscillatoria amphibian obtained at the concentration of $17.95 \mathrm{mg} / \mathrm{l}$ as concentration of potassium in basal medium. Chlorococum humicolum is at $16 \mathrm{mg} / \mathrm{l}$. Selanastrum at $32 \mathrm{mg} / \mathrm{l}$ and Coelastrum at 64 $\mathrm{mg} / \mathrm{l}$.

Chloride: It is essential for photosynthesis in algae.It is needed for Hill reactions ATP formation. FMN catalysed photophosphorylation reaction (Vernon, et al., 1965) and 16 different requirement of chloride for Phytoplankton. Whitton and Shehata was reported different requirement of chloride for phytoplankton. Sliehata, and Whitton., (1982) reported $26.46 \mathrm{mg} / \mathrm{l}$; Antarikanonda, (1982) indicated $139.6 \mathrm{mg} / \mathrm{l}$ chloride for Cyanophyceae. Whereas Guillard, (1973) noted $17.35 \mathrm{mg} / \mathrm{l}$ Chloride in medium for diatoms. In the experiment, Chloride with the range of 4.00 - $128.00 \mathrm{mg} / \mathrm{l}$, the growth of Chlorococum humicolum and Coelastrum spharicum were maximum at $32.00 \mathrm{mg} / \mathrm{l}$ Oscillatoria amphibian showed maximum growth at $16.00 \mathrm{mg} / \mathrm{l}$.

Iron: Iron is a key element in plant metabolism. The rate of photosynthesis is lowered by iron deficiency. The iron requirement in biological oxidation reduction applies to algae as well as to other living organisms. A direct correlation between photosynthetic activity and chlorophyll content was demonstrated in Chlorella pyrinoidosa by Emerson, (1929); who reported that reduced chlorophyll content is the only factor responsible for reduction of photosynthesis in iron deficient cells. Iron has been reported to be involved in nitrate reduction by Chlorella, (Trubochev et al., 1976) and nitrate has been demonstrated in sub cellular preparation of Anabaena cylindrica (Hattori and Yesugi,1968). The level of iron is directly related to the next of hydrogen development in Scenedesmus (Yanagi and Saba, 1966).

The range of iron is $0.2 \mathrm{mg} / \mathrm{l}$ and $16.00 \mathrm{mg} / \mathrm{l}$ against $1.2 \mathrm{mg} / \mathrm{l}$ iron in BG-11, maximum growth of Oscillatoria amphibian and Selenastrum wastii and $2.00 \mathrm{mg} / \mathrm{l}$ and for Chlorococcum humicolumn, were the same in basal medium. 


\section{International Journal of Science and Research (IJSR) \\ ISSN (Online): 2319-7064}

Index Copernicus Value (2013): 6.14 | Impact Factor (2015): 6.391

\section{Acknowledgments}

Authors would like to thanks Dr. S. N. Malode, Head, P. G. Department of Botany, GVISH, Amaravati and Dr. B. G. Ambatkar, Principal, R. S. Bidkar College, Hinganghat Dist. Wardha for providing the facilities. Authors would also like to thanks Prof. Sebastian Kulthassary for editing the manuscript.

\section{References}

[1] Antarikononda, P. 1982. Effect of salinity on growth, nitrogen fixation and sodium uptake of rapidly growing $\mathrm{N}_{2}$ fixing blue green algae Anabaena sp. QAI, Microbios, 34:177-184.

[2] Chu, S. P. 1942. The influence of the mineral compositions of the medium on the growth of the planktonic algae, I. Methods and culture media. J. Ecol. 30:284-325.

[3] Craig, M., McCready, L., Luu, H.A., Smillie, M.A., Dubord, P. and Holmes, C.F.B. 1993. Identification and characterization of hydrophobic Microcystis in Canadian freshwater cyanobacteria. Toxicon, 31:15411549.

[4] Dixon, G.K. and Merrett, M.J. 1988. Bicarbonate utilization by the man diatom Phaeoductylum tricortintum Bohlin. New Nycol. 104: 47-51.

[5] Emerson, R. 1929. J. Gen. Physiol. 19:609.

[6] Geoghegan, M.J. 1953. Experiments with Chlorella at Jealotts Hill. In algal culture from laboratory to piolet plants, ed. Burlew, J.S. Carnegie Institute, Washington DC.pp.182-189.

[7] Gerloff, C.C., Fitzerland, G.P. and Skoog, P.1950. The mineral nutrition of Chroococcus periocystis. Artier.]. Botany. 37: 835-840.

[8] Guillard, R.R.L. 1973. Growth media for fresh water in: Handbook of phycolngical methods, culture methods and growth measurements. J.R. Stein, Cambridge university Press. pp. 16-17.

[9] Hattori, A and Uesugi, I 1968a. Purification and properties of nitrite reductase from the blue green alga Anabaena cylindrical 1. Pl. Cell Physiol.9:689-699.

[10]Hopkins, E.F. 1930. The necessity and functions of manganese in the growth of Chlorella sp. Science N.Y. 72:609-610.

[11] Hutner et al., 1950 Proc. Am. Philos. Soc. 94:152-170

[12] Jawale, A. K, Kumawat, D. A. and Chaudhari, N. A. 2010. Carteria maharashtrensis, a new member of Volvocales, Journal of Chemo and Biosphere, 1(1):7880.

[13] Ketchum 1954. Mineral nutrition of phytoplankton. Ann. Rev. plant PhysioL, 5: 55-74.

[14] Ketchum, B. H. and Redfield, A. C. 1949. The Cell. Comp. Physia., 33:281.

[15] Ketchum, B.H. 1939. The absorption of phosphate and nitrate by illuminated culture of Nitzscia closterium, Amer. J. Bot 26:399-407.

[16] Krauss, R. W. 1958. Physiology of the fresh water algae. Ann. Rev. Plant Physiol., 9:207-244.

[17] Marathe, K. V. 1969. Studies on soil algae of India. II. Soil algae from the cultivated fields of Jalgaon M.S. J. Univ. Bombay, 38: 69-72.

[18] Myers, J. 1951. Physiology of the algae. Ann. Rev.
Microbiol, 5:157-180.

[19] Myers, J. 1953. Growth characteristics of algae in relation to the problems of mass culture. In algal culture from laboratory to piolet plants, ed. Burlew, J.S. Carnegie Institute, Washington DC.pp.37-54.

[20] Myers, J. and Clark, L. B. 1944 Culture conditions and the development of the photosynthetic mechanism. II. An apparatus for the continuous culture of Chlorella. $J$. Gen. Physiol., 28: 103-112.

[21] Noack, K.A., Pirson, and Stegmann, G. 1940. De liedarf an supfiementen hei Chlorella. Naturwiss., 28: 172-173

[22] Provasoli, L. and Pintner, I. J. 1960. Artificial media for freshwater algae: problems and suggestions. - R. T. Hartman (ed.) The Ecology of Algae. Pymatunig Laboratory of Field Biology Special publication 2, University of Pittsburgh pp. 84-96.

[23] Richmond, A., Karg, S. and Boussiba, S.1982. Effects of bicarbonates and carbon dioxide on the competition between Chlorella vulgaris and Spirulina platensis. Plant Physiol. 23(7): 1411-1417.

[24] Rodhe, N. 1948. Environmental requirement of fresh water plankton algae. Symbole Sown. Upsalienses, 10:144.

[25] Scott, G. T. 1944. Cation exchanges in Chlorella pyrenoidosa. I. Cell Comp. Physiol., 23: 47-58.

[26] Sharon, M. and Belinger, R.G. 1976. Effect of relatively high concentration of $\mathrm{Cu}, \mathrm{Fe}, \mathrm{K}$ and $\mathrm{Mg}$ on the growth of Scenedesmus dinzurphus in pure culture. Phykos., 15(112):11-18.

[27] Sliehata, F.H.A. and Whitton, B. A. 1982. Zn tolerance in strain of the blue green alga Anacystis nidulanns, Sr. Phycol. J., 17: 5-12.

[28] Tanda, T. 1951. The photosynthetic efficiency of carotenoid pigments in Navicula minima. Amer. $J$. Botany, 38: 272-276.

[29] Trabochev, N. I., Gitelzon, Kalcheva, G.S., Barashkov, V.A. , Belyanin, V.N. and Andeeva, R.I. 1976. Biochemical composition of several blue green algae Nova Hedwigia, 46(1-4):1-93.

[30] Trelease, S. F. and Selsam, M.E. 1939. American J. Rot., 26:339-341.

[31] Vernon, L.P. and Avron, M. 1965. Photosynthesis A Rev. Biochem., 34:269-296.

[32] Yanagi, S and Saba, T. 1966. Changes in hydrogenase activity during the synchonus growth of Acenedesmus obliquous D-3 Pl, Cell Physiol. Tokyo, 1:593-598. 